May 2021

\title{
Supporting STEM Faculty of Large Enrollment Undergraduate Courses: A Mixed Methods Study of Impact
}

Lindsay B. Wheeler

University of Virginia, Isb4u@virginia.edu

Follow this and additional works at: https://digitalcommons.georgiasouthern.edu/ij-sotl

\section{Recommended Citation}

Wheeler, Lindsay B. (2021) "Supporting STEM Faculty of Large Enrollment Undergraduate Courses: A Mixed Methods Study of Impact," International Journal for the Scholarship of Teaching and Learning: Vol. 15: No. 1, Article 7.

Available at: https://doi.org/10.20429/ijsotl.2021.150107 


\title{
Supporting STEM Faculty of Large Enrollment Undergraduate Courses: A Mixed Methods Study of Impact
}

\begin{abstract}
A plethora of literature exists identifying the importance of engaging students in learning within Science, Technology, Engineering, and Math (STEM) undergraduate courses, making professional development (PD) for faculty teaching these courses vital. Yet few studies of PD programs focus on STEM faculty, incorporate direct measures of faculty practice, and seek to understand the student experience in courses taught by these faculty. In this study, I examine the impact of a program for faculty teaching large enrollment STEM courses on their perceptions, instructional practices, and student perceptions of learning. The program included a week-long course design institute ( $35 \mathrm{hrs})$ and a year-long STEM Faculty Learning Community (STEM-FLC) that met monthly (14 hrs). Data included faculty surveys, course syllabi, observations of teaching, and Student Evaluations of Teaching (SETs). Results suggest the program helped instructors create more learning-focused courses and implement student-centered instructional practices to differing degrees. Despite the STEM-FLC, faculty still perceived barriers to implementing their course design. Students' perceptions of course instruction and self-reported learning in these courses highlighted the importance of in-class activities. Finally, when the course design and instructional practice were aligned, students had more positive perceptions and reported higher learning gains compared to students in courses with misalignments in design and practice. Based on the findings of the study and connection with PD literature, I provide a set of essential PD features that may enable STEM faculty to make meaningful and lasting changes to practice.
\end{abstract}

\section{Keywords}

STEM, faculty development, instruction, professional development

\section{Creative Commons License} cc) $($ ) $९$

This work is licensed under a Creative Commons Attribution-Noncommercial-No Derivative Works 4.0 License. 
IJ-SoTL, Vol. 15 [2021], No. 1, Art. 7

\title{
Supporting STEM Faculty of Large Enrollment Undergraduate Courses: A Mixed Methods Study of Impact
}

\author{
Lindsay B.Wheeler \\ University of Virginia \\ Received: I4 September 2020;Accepted: I3 May 202 I
}

\begin{abstract}
A plethora of literature exists identifying the importance of engaging students in learning within Science, Technology, Engineering, and Math (STEM) undergraduate courses, making professional development (PD) for faculty teaching these courses vital. Yet few studies of PD programs focus on STEM faculty, incorporate direct measures of faculty practice, and seek to understand the student experience in courses taught by these faculty. In this study, I examine the impact of a program for faculty teaching large enrollment STEM courses on their perceptions, instructional practices, and student perceptions of learning. The program included a week-long course design institute (35 hrs) and a year-long STEM Faculty Learning Community (STEM-FLC) that met monthly (I4 hrs). Data included faculty surveys, course syllabi, observations of teaching, and Student Evaluations of Teaching (SETs). Results suggest the program helped instructors create more learning-focused courses and implement student-centered instructional practices to differing degrees. Despite the STEM-FLC, faculty still perceived barriers to implementing their course design. Students' perceptions of course instruction and self-reported learning in these courses highlighted the importance of in-class activities. Finally, when the course design and instructional practice were aligned, students had more positive perceptions and reported higher learning gains compared to students in courses with misalignments in design and practice. Based on the findings of the study and connection with PD literature, I provide a set of essential PD features that may enable STEM faculty to make meaningful and lasting changes to practice.
\end{abstract}

\section{INTRODUCTION}

First-year courses are vital to the retention and success of students in Science, Technology, Engineering and Mathematics (STEM) undergraduate disciplines (PCAST, 20I2). Important for student success and retention are interactions with peers and faculty (Freeman et al., 20I4; Kuh, Cruce, Shoup, Kinzie, \& Gonyea, 2008; Schneider \& Preckel, 2017), yet the majority of STEM courses in the United States are still predominately lecture (Stains et al., 2018). Even when STEM courses include student-centered instruction, variation in implementation may have differential effects on students (Cooper, Downing, \& Brownell, 2018; Eren-Sisman, Cigdemoglu, \& Geban, 20I8). Faculty professional development (PD) programs hold promise for changing STEM instructional practice (e.g., Czajka \& McConnell, 2016; Jones, 2017); however, few studies go beyond faculty self-report measures. Given the importance of structure and support during active learning (Haak, HilleRisLambers, Pitre, \& Freeman, 20I I) and the call for more direct measures of impact (Stes, Min-Leliveld, Gijbels, \& Van Petegem, 2010), understanding instruction during and following PD is essential. Thus, this study aims to add to this body of literature by exploring the impact of a program for STEM faculty of large-enrollment courses on instructional practices and student perceptions and self-reported learning.

\section{LITERATURE REVIEW}

There are a variety of different faculty PD approaches in higher education: I) short workshops, 2) multi-day workshops/institutes, 3) one-on-one support, and 4) continued small group support.

\section{Faculty Professional Development}

Short workshops are a frequent method Centers for Teaching and Learning (CTLs) use for sharing best practices with large numbers of faculty (e.g., Rathbun, Leatherman, \& Jensen, 2016). However, research suggests short, isolated workshops with no follow-up have little impact on instruction (Rathbun, et al., 2016; Stes et al., 2010). Longer, multi-day institutes typically focus on course re-design using a backward design approach (Ebert-May et al., 20 I I; Palmer, Streifer, \& Williams-Duncan, 2016). While these types of programs change faculty perceptions and course syllabi (Palmer et al., 2016), there are mixed findings on the impact of these types of programs on STEM instructional practice (e.g., Ebert-May et al., 201 1; Wheeler \& Bach, 2020). For example, when exploring Biology faculty practice, Ebert-May and colleagues (20II) found the majority of instructors used lecture-based teaching, and these practices did not shift following a 5-day summer workshop. Conversely, in a study comparing instructional practice of STEM faculty who had and had not participated in a 5-day course design institute, Wheeler \& Bach (2020) found participating faculty had significantly more student-centered instructional practices compared to non-participating faculty, even when controlling for class size. Thus, further research on these types of programs are needed to understand their impact on instruction.

Other forms of PD include one-on-one support such as consultations and coaching (e.g., Czajka \& McConnell, 20I6; Jones, 20I7), which are intended to reform faculty practice. This PD continues to result in positive outcomes for STEM instruction (Czajka \& McConnell, 20I6; Sunal et al., 200 I), particularly for faculty teaching large-enrollment courses (Jones, 2018). While effective, this approach is time consuming and limited in its ability to achieve large-scale impact. Finally, small group support for faculty most often take the form of a community of practice (CoP) or faculty learning community (FLC) to support change (e.g., Tomkin, Beilstein, Morphew \& Herma, 2019). More recently, pedagogy courses (e.g., Birt et al., 2019) and cross-institutional CoPs (e.g., Gehkle \& Kezar, 20I7) have been implemented to support STEM faculty. The studies on small group PD demonstrate the importance of continual peer engagement for faculty confidence and use of new practices (e.g., Hayward \& Laursen, 20 I8; Tomkin et al., 2019). 


\section{Limitations in Current Assessment of Faculty Professional Development}

While not a comprehensive list, Table I reviews studies on faculty PD and illustrates important gaps in the literature. The majority of the studies measure PD impact on faculty perceptions (i.e., program experiences, beliefs, self-efficacy) and nearly all studies measure instructional practice. Of those studies exploring practice, nearly half use self-report (e.g.,Attitudes about Teaching Inventory (ATI), syllabi, Teaching Perspectives Inventory (TPI)) and half use observations (e.g., Classroom Observation of Undergraduate STEM (COPUS), Reformed Teaching Observation Protocol (RTOP)).Very few studies examine the impact of PD on student outcomes, with only one study focused on STEM courses (e.g., Jones, 2018). To my knowledge, no studies examine a STEM PD that incorporates multiple PD approaches and seeks to measure faculty perceptions, instruction, and student outcomes.

\section{PURPOSE}

In the present study, I sought to answer the following research questions:

I. To what extent do faculty use student-centered instructional practices following engagement in course redesign and a STEM learning community?

2. What are students' perceptions of course instruction and self-reported learning in re-designed large-enrollment STEM courses?

3. What factors influence instructional practices and student perceptions of STEM courses re-designed by faculty in the program?

\section{METHODS}

This convergent parallel mixed methods study with a quantitative emphasis (Cresswell \& Clark, 20I I) occurred at a mid-size research intensive institution in the Mid-Atlantic region with three faculty cohorts engaging in the program between 20132016. Quantitative data include faculty Likert survey responses and Student Evaluations of Teaching (SETs), observational data, and syllabus scores. Qualitative data include faculty open-ended survey responses, SET comments, and course syllabi.

\section{CTL STEM Faculty Program}

In our CTL, we developed a program for faculty to engage in our summer Course Design Institute (CDI) to redesign an introductory, large-enrollment STEM course and participate in a yearlong FLC. Each faculty received a stipend upon completion of the program.

\section{Course Design Institute}

The initial experience for each faculty member included participation in CDI as a cohort. CDI is an intensive, five-day workshop (35 hours) where faculty are introduced to an integrated, backward design approach to course design (Fink, 20I3). Learning teams consist of 5-7 faculty and are run by a trained facilitator. The learning team engages with each other throughout the week and provides feedback to each other on their course design, resulting in a learning-focused, aligned course as articulated in a syllabus document.' The faculty who participated in the program were grouped into I-2 learning teams at CDI each year.

\section{STEM Faculty Learning Community}

After completing CDI together, faculty continued on in a yearlong STEM- FLC ( I 4 hours). The STEM-FLC was designed using the FLC literature (Cox, 2004) and the needs of the faculty within our local context. The STEM-FLC was facilitated by a CTL member and served as a space for faculty to learn from and encourage one another in their course re-design and implementation. Learning-focused pedagogy topics and literature were read and discussed during the monthly meetings. The objectives of the STEM-FLC included:

- $\quad$ expanding instructors' knowledge of evidence-based pedagogical practices;

- facilitating instructors' conceptualization of their courses in a learning-focused, integrated paradigm; and

- increasing instructors' confidence in and implementation of learning-focused course design.

In addition to the learning community, faculty engaged in peer observations and consulted with a CTL member at least once during the program. Each STEM-FLC member produced a portfolio upon completion of the program that contained their course syllabus, analysis of student data, and a personal reflection on their experience in the program.

\section{Program Participants}

A total of 26 faculty across II STEM departments engaged in the program and consented to participate in the IRB-approved study (Table 2). These participants taught $\sim 5,436$ undergraduate students during the inaugural sessions of their redesigned courses,

\begin{tabular}{|c|c|c|c|c|c|c|}
\hline Study & PD & $\begin{array}{l}\text { Faculty PD } \\
\text { perceptions }\end{array}$ & $\begin{array}{l}\text { Faculty cognitive and } \\
\text { affective perceptions }\end{array}$ & \begin{tabular}{|c|}
$\begin{array}{c}\text { Instructional } \\
\text { practices }\end{array}$ \\
\end{tabular} & $\begin{array}{c}\text { Student } \\
\text { perceptions }\end{array}$ & $\begin{array}{l}\text { Student } \\
\text { learning }\end{array}$ \\
\hline Ebert-May et al. $(20 \mathrm{II})^{*}$ & 5-day institute or CoP/FLC & experience & experience, knowledge & RTOP & & \\
\hline Lauridsen \& Lauridsen (20I8) & CoP/FLC with I-o-I support & satisfaction & knowledge, skills & observation & & \\
\hline Odalen et al. (2018) & Pedagogy course & satisfaction & self-efficacy & ATI & & \\
\hline Rathbun et al. (2016) & workshops & attendance & & syllabi & SETs & grades \\
\hline Meizlish et al. (20I7) & workshops \& CoP/FLC & satisfaction & & & SETs & SETs \\
\hline Birt et al. $(2109)^{*}$ & pedagogy course & & beliefs, agency & observation & & \\
\hline Czajka \& McDonnell (20I6)* & I-o-I support & & beliefs & RTOP & & \\
\hline Eiselein (2019) & CoP/FLC & & knowledge, self-efficacy & self-reported & & \\
\hline Hubball et al. (2005) & CoP/FLC & & TPI & TPI & & \\
\hline Hutchins \& Friedrichson $(2012)^{*}$ & 3-day institute & & knowledge, beliefs & observations & & \\
\hline Sunal et al. $(200 \mathrm{I})^{*}$ & I-o-I support & & self-efficacy & self-reported & & \\
\hline Gibbs \& Coffee (2004) & workshops, CoP/FLC & & teaching skills & ATI & student survey & \\
\hline Tomkin et al. (2019) ${ }^{*}$ & CoP/FLC & & & COPUS & & \\
\hline Jones $(2018)^{*}$ & I-o-I support & & & COPUS & student survey & grades \\
\hline
\end{tabular}


with an average class size of 120 students. In year 3, six faculty participated in the program as a departmental team to redesign a series of courses.

\begin{tabular}{|l|c|l|l|c|}
\hline Table 2. Overview of STEM-FLC & participants \\
\hline \multicolumn{1}{|c|}{ Discipline } & $\mathbf{n ~ ( \% )}$ & & Faculty rank & $\mathbf{n ~ ( \% )}$ \\
\hline Environmental Science & $\mathrm{I}(3.85)$ & & Non-tenure track & $\mathrm{II}(42.3 \mathrm{I})$ \\
\hline Physics & $\mathrm{I}(3.85)$ & & Tenure-track & $4(15.38)$ \\
\hline Astronomy & $2(7.69)$ & & Tenured & $\mathrm{II}(42.3 \mathrm{I})$ \\
\hline Chemistry & $2(7.69)$ & & Cohort & $\mathbf{n}(\%)$ \\
\hline Math & $6(23.08)$ & & Year I (20I3-20I4) & $8(30.77)$ \\
\hline Biology & $7(26.92)$ & & Year 2 (20I4-20I5) & $8(30.77)$ \\
\hline Engineering & $7(29.92)$ & & Year 3 (20I5-20I6) & $\mathrm{I} 0(38.46)$ \\
\hline
\end{tabular}

\section{DATA COLLECTION AND ANALYSIS}

To answer research question I, post-program survey responses, course syllabi, and classroom observations were obtained to characterize teaching practice. I used a constant comparative method to analyze 18 of the $26(69.2 \%)$ participants' open-ended survey responses on faculty's self-reported instructional approaches to identify themes related to implementation of their re-designed course (Miles \& Huberman, 1994). Two trained graduate students analyzed pre- and post-CDI syllabi for 23 of the 26 (88.5\%) participants' redesigned courses using a previously developed and validated syllabus rubric (Palmer, Bach, \& Streifer, 20I4). The graduate students individually scored each syllabus, discussed any discrepancies, and came to an agreement on a final score, which could range from 0 (content-focused) to 46 (learning-focused). Syllabus scores were categorized as content-focused (0-16), transitional (17-30) and learning focused (3I-46). A non-parametrics Wilcoxon sign ranked test was used to identify significant differences between pre- and post-syllabus scores. A normalized gain score, $<<g\rangle>$, was also calculated for each participant to identify the extent to which their syllabus improved.

I gathered I-2 observations of year $2 \& 3$ participants $(n=17$, 94.4\%) during the semesters in which they engaged in the STEMFLC using the Classroom Observation Protocol for Undergraduate STEM (COPUS). ${ }^{3}$ COPUS provides information on the percentage of time the instructor and students spent engaging in particular behaviors ( 13 instructor and 12 student behaviors). These data were then converted into COPUS profiles (copusprofiles.org); these profile categories were originally developed from a large scale observational study of over 2,000 class periods (Stains et al., 2018). The three COPUS profiles include didactic instruction (i.e., more than $80 \%$ lecture), interactive lecture (e.g., lecture with clickers), and student centered instruction (e.g., Process Oriented Guided Inquiry Learning (POGIL), group work) (for more information about the creation of COPUS profiles, see Stains et al., 2018).

To answer research question 2, I utilized the university-wide SET questions. ${ }^{4}$ Completion rate ranged from $40-100 \%$ (Mean $=65.74 \pm 18.58 \%$, Median $=58.33 \%$ ) for the $3 \mathrm{I}$ courses taught by participants. Students' perceptions of their courses instructional practices were measured through the SET open-ended comments and three Likert scale questions: "The course's goals and requirements were defined and adhered to by the instructor", "The instructor was approachable and made himself/herself available to students outside the classroom", and "Overall, the instructor was an effective teacher". Student's learning was measured through participants' post-program survey report of student learning and two Likert scale SET questions on student's self-reported learning:"I learned a great deal in this course" and
"Overall, this was a worthwhile course". ${ }^{5}$ I also used participants open-ended survey responses to triangulate student perceptions of learning in the course.

To answer research question 3, the open-ended post-program survey and open-ended SET responses were coded using a constant comparative method to identify common ideas related to barriers and supports for participants in implementing their course design (Miles \& Huberman, 1994). To identify factors related to instructional practices from the student perspective, I first compared the syllabus scores and COPUS profile categories for each instructor who had both data sets $(n=15)$ to identify areas of course misalignment. Course misalignment was grouped into three categories; aligned, partially aligned, and misaligned (Table 3). For example, a participant who had a content-focused syllabus and a student-centered COPUS profile would have a 'not-aligned' course. SETs were then explored and compared for courses that fell into these three categories.

\begin{tabular}{|c|c|c|c|}
\hline \multirow{2}{*}{$\begin{array}{l}\text { COPUS profile } \\
\text { categories }\end{array}$} & \multicolumn{3}{|c|}{ Syllabus categories } \\
\hline & Content-focused & Transitional & Learning-focused \\
\hline Didactic & fully aligned & partially aligned & not aligned \\
\hline Interactive lecture & partially aligned & fully aligned & partially aligned \\
\hline Student Centered & not aligned & partially aligned & fully aligned \\
\hline
\end{tabular}

\section{RESULTS}

Each section describes the quantitative data followed by qualitative data to help explain or deepen understanding of the quantitative findings.

\section{Instructional Practice}

\section{Self-reported changes in practice}

Overall, participants agreed that the program helped improve their teaching and helped them implement more student-centered instruction (Table 4). When asked about these changes, participants tended to comment on two main ideas: I) course alignment, and 2) student engagement. First, participants continually explained the rationale for course modifications as they related to alignment of learning objectives to course assessments and activities. Further, their learning objectives de-emphasized content and emphasized higher order thinking. For example, when asked what changed one participant stated,"Nothing exotic! I added pre-class assessments due online before class and incorporated additional practice problems that prompted higher-level thinking" (FII).

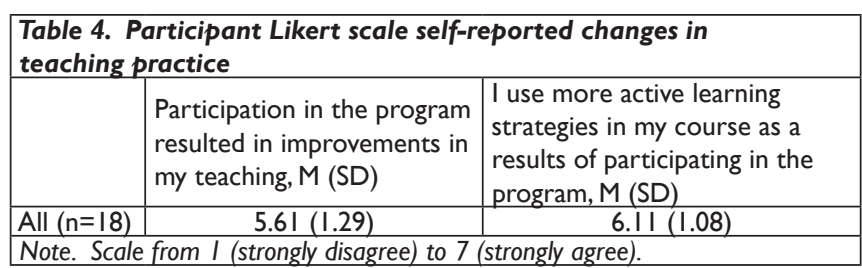

Second, all participants discussed how they had revised their instruction to incorporate more discussions, problem solving, and/ or group work; however, the extent to which they made changes differed. For example, some participants continued to lecture but integrated some iClicker questions, while others completely redesigned their class to student-centered instruction. One participant stated, "I stopped using long stretches of lecture. I came to realize that having them do the problems is a good use of class time" 


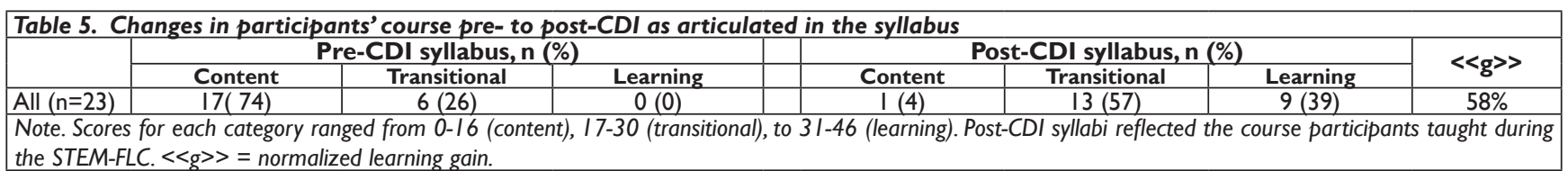

(F3). These changes around alignment and instruction mirrored the programs focus on aligned course design and use of evidencebased strategies.

\section{Changes in course syllabi}

Participants entered into CDI with very content-focused syllabi (Table 5), characterized by contractual-type language and an emphasis on policies and grades. By the end of CDI, instructors' syllabi scores significantly shifted to more learning-focused $(\mathrm{t}=276$ $n=23, p<.00 \mathrm{I}$ ), incorporating inviting language, aligning learning objectives to course assessments and activities, and emphasizing significant learning over content knowledge. These syllabus changes demonstrate how instructors integrated the evidencebased teaching practices learned during CDI into their course design.

As an example, one participant's pre-CDI syllabus course description focused on content and topics to be covered within their biology course:

A broad yet intensive introduction to modern biology designed for prospective natural science majors and premedical students. Chemistry fundamentals, biological structure and function, cell biology, and genetics are covered. This course is required for all biology majors and is a prerequisite for most upper-level biology courses. (pre-CDI syllabus)

It went on to describe the policies and ended with a schedule that included chapters to read and exam dates. In their post-CDI syllabus, the description shifted to exploring how living things work:

Humans, butterflies, grass, bacteria, and every other living thing share the common feature of being composed of one or more of the fundamental unit of life-the cell. In this course, we will explore the common features and activities of the cell, how those are encoded and orchestrated by the instructions for life within that cell, how cells interact with their environment, and how the diversity of life can be achieved. If you think that biology is simply describing and memorizing, you're in for a pleasant surprise! (post-CDIsyllabus)

Following the description was a set of explicit learning objectives, details on pre-class homework assignments, a schedule with specific chapter sections that are required for the course, and a new section on 'getting help'. The changes in the language, tone, alignment, and emphasis demonstrate the shift from a content- to learning-focused syllabus.

\section{Observations of practice}

Participants' instructional practice were mostly split between student-centered instruction and lecture (Table 6). From individual COPUS behaviors, on average, participants lectured $\sim 70 \%$ and integrated writing and posed questions to the whole class approximately one-third of that lecture time (or $25 \%$ of entire class time). Participants used the remainder of class for adminis-

Table 6. Participants observed instructional practice

\begin{tabular}{|l|c|c|c|}
\hline & $\begin{array}{c}\text { Didactic (more than } \\
80 \% \text { lecture), } \mathrm{n}(\%)\end{array}$ & $\begin{array}{c}\text { Interactive lecture, } \\
\mathrm{n}(\%)\end{array}$ & $\begin{array}{c}\text { Student-centered, } \\
\mathrm{n}(\%)\end{array}$ \\
\hline All $(\mathrm{n}=17)$ & $8(47.1)$ & $\mathrm{I}(5.8)$ & $8(47.1)$ \\
\hline \multicolumn{4}{|l|}{ Note. Observation data based upon COPUS profiles. } \\
\hline
\end{tabular}

trative tasks (e.g, going over homework), clicker questions, group work, and whole class discussions.

\section{Student Perceptions \& Self-reported Learning}

\section{Student perceptions of practice}

Students' perceptions of their instructor, as evidenced in responses to SETs, were overall positive (Table 7). As an example, when asked to comment about the course, one student responded:"Great professor. Professor [F6] is an amazing teacher who wants all of her students to do well in her class" (SET). It was clear that student felt their instructor cared about them and their learning. Participants similarly felt students were more engaged and interested in the course than students in the course before they participated in the program (Table 8).

\begin{tabular}{|c|c|c|c|c|c|c|}
\hline & \multicolumn{2}{|c|}{$\begin{array}{l}\text { The course's goals } \\
\text { and requirements } \\
\text { were defined and } \\
\text { adhered to by the } \\
\text { instructor }\end{array}$} & \multicolumn{2}{|c|}{$\begin{array}{l}\text { The instructor was } \\
\text { approachable and } \\
\text { available to students } \\
\text { outside the class- }\end{array}$} & \multicolumn{2}{|c|}{$\begin{array}{l}\text { Overall, the } \\
\text { instructor was an } \\
\text { effective teacher }\end{array}$} \\
\hline & $\begin{array}{l}\text { Mean } \\
(\mathrm{SD})\end{array}$ & \% Agree & $\begin{array}{l}\text { Mean } \\
(\mathrm{SD})\end{array}$ & \% Agree & $\begin{array}{l}\text { Mean } \\
(\mathrm{SD})\end{array}$ & \% Agree \\
\hline $\begin{array}{l}\text { All cours- } \\
\text { es }(n=26)\end{array}$ & $4.28(.45)$ & 87.2 & 4.31 (.44) & 85.1 & $4.10(.7 I)$ & 78.1 \\
\hline
\end{tabular}

Qualitative responses also mirrored these results. For example, a participant stated, "My students were engaged, even in a 90-person class, and I got them interacting with primary literature", and "The students were engaged, excited and admitted they liked being pushed outside of their comfort zones" (F6, post-survey). Student responses mirrored participants' sentiments. For example, one student stated, "Professor [FI3] was helpful and responsive to different students' needs. He is a very engaging teacher and you can tell he is passionate about this subject" (SET).

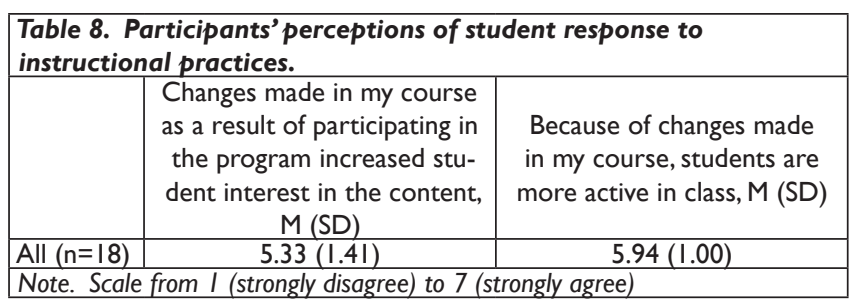

\section{Student reported learning}

Similar to students' perceptions of practice, the majority of students agreed that they learned a lot in the course (Table 9). When students mentioned learning in their SET comments, they commonly stated they learned the material well because of the use of student-centered instructional practices. For example, one student stated,"I feel that I have learned a lot from this course. It was challenging and at times frustrating. I thought that group work helped a lot though" (SET). Another student stated "Even though I had already taken AP Physics C: Mechanics in high school, I nonetheless learned plenty of new material from taking this course. I enjoyed the lectures a great deal, especially the iClicker 
questions" (SET). In these courses and others taught by participants, students recognized the relationship between learning and the class activities.

\begin{tabular}{|l|c|c|c|c|}
\hline Table 9. Students' perception of learning \\
\hline & $\begin{array}{r}\text { I've learned a great deal in } \\
\text { this course }\end{array}$ & \multicolumn{2}{|c|}{$\begin{array}{c}\text { Overall, this was a } \\
\text { worthwhile course }\end{array}$} \\
\cline { 2 - 5 } & Mean (SD) & $\%$ Agree & Mean (SD) & $\%$ Agree \\
\hline All ( $\mathrm{n}=26)$ & $4.17(.46)$ & 82.1 & $3.10(.64)$ & 77.9 \\
\hline $\begin{array}{l}\text { Mean values on a scale from I (strongly disagree) to } 5 \text { (strongly agree). \% Agree } \\
\text { included both agree (4) and strongly agree (5). }\end{array}$
\end{tabular}

\section{Factors Influencing Teaching and Learning}

\section{Supports for implementing re-designed course}

Factors that promoted participants' use of student-centered learning in the classroom included: I) STEM-FLC discussions and 2) motivation for continued improvement of teaching. First, many participants explicitly discussed the importance of the STEM-FLC discussions in providing feedback and suggestions for improving their practice. For example, participants stated: "Having the colleagues to draw on individually for their experiences in the [STEM-FLC] meetings helped throughout the semester" (F3) and "Being part of a learning community was critical in sharing ideas and making corrections" (F2). The opportunities to hear from the program facilitators and peers was invaluable to participants in making meaningful changing to their practice.

Second, participation in the program also helped motivate faculty to continue improving their teaching. When asked if the program would promote future engagement in PD, 17 participants $(94.4 \%)$ agreed or strongly agreed. From analyses of openended questions, participants' motivation came from their value of course design and student-centered learning strategies, and the motivation observed by other program participants. For example, one participant stated,"The [STEM-FLC] experience left me with a lot of excitement about the coming semester though, and I am already starting to plan for what I will do differently in 20 I4" (FI3).Another participant explained how the two components of the program were motivating,"The combination of both the CDI (inspiration) and the [STEM-FLC] (perspiration) is the primary reason that the assessments were revised" (F5).

\section{Barriers to implementing re-designed course}

While participants were motived to implement their re-designed course and had the support of the STEM-FLC, there still existed factors that hindered their ability to do so.These factors included: I) institutional structures and 2) beliefs about teaching. First, participants understood the increased amount of time it takes to develop and implement a course that is student-centered, and the lack of time and support in doing so was evident in their comments. For example, one participant stated,

The lack of teaching assistant help is a hindrance. Grading the students' analysis of media accounts, and their final media projects, was VERY time consuming. Ideally, we would have additional teaching assistants to help with the grading, but that does not seem possible right now. Thus, I am looking at ways to streamline the grading. (F5)

This participant clearly felt they needed more human resources to be able to effectively implement their course re-design in the ways that they would like, and without it, they were going to have to change the major assignment.

Further, logistics such as class size, classroom, and technology issues were also reported as impediments to implement- ing student-centered instruction. For example, when asked what hindered their ability to incorporate what they learned in the program, participants indicated, "The number of logical (sic) issues were impediments (i.e. class size, classroom layout)" (F2), and "Technical issues with internet use by the class as a whole limited the use of Learning Catalytic software to collect student responses" (FII). Thus, the institutional structures were limiting participants rather than supporting them.

Second, almost all participants' beliefs aligned with student-centered instructional practices in their courses; however, a few struggled with their beliefs about teaching and the value placed on teaching. When asked about whether they would continue to use student-centered instructional practices and learning-focused course design strategies, one participant stated:

Likely, it's the way to go. Still not $100 \%$ convinced that this is better than the 'old days' but teaching like everything else undergoes changes and some are better, some are not. Time will tell whether today's youth turn out to be better educated than 50 years ago! Still doubt that. (F4)

This participant's beliefs about teaching appear to not allow them to consider that new approaches to engaging students in learning could be effective.

\section{Course design alignment}

Descriptive differences existed in students' perceptions of courses identified as aligned, partially aligned, and not aligned in their course design and teaching practice (Table 10). SETs were extremely low for the one not aligned course, and students commented on this misalignment:

Lots of things were tough about this class. The lectures did not prepare me enough for the brutal homework assignments. The assignments themselves were really vague and difficult to figure out exactly what I was supposed to do. And the grading seemed somewhat arbitrary. (SET).

The lack of clarity observed in this course was voiced by many students. Further, the learning focus of the course itself was lost on students. For example, one student stated:

Not only have I taught myself all of the course material, I also feel that I have little knowledge outside of my homework assignments. Rather than a learning experience, homework turned into an arduous task that was only met by unhelpful TA assistance. There should be strict, specified guidelines for exams and homework to know how each task was graded. (SET)

Thus, it appears the course intent (i.e., syllabus) and implementation (i.e., class time, assignments) were misaligned and were perceived by students to hinder their learning experiences.

Table 10. Students' perceptions and reported learning for courses with differing levels of alignment.

\begin{tabular}{|l|c|c|c|}
\hline & $\begin{array}{c}\text { Not } \\
\text { aligned } \\
(\mathrm{n}=1)\end{array}$ & $\begin{array}{c}\text { Partially } \\
\text { aligned } \\
(\mathrm{n}=8)\end{array}$ & $\begin{array}{c}\text { Fully } \\
\text { aligned } \\
(\mathrm{n}=6)\end{array}$ \\
\hline $\begin{array}{l}\text { The course's goals and requirements were } \\
\text { defined and adhered to by the instructor }\end{array}$ & $2.73(0)$ & $4.25(.45)$ & $4.55(.15)$ \\
\hline $\begin{array}{l}\text { The instructor was approachable and avail- } \\
\text { able to students outside the classroom }\end{array}$ & $3.49(0)$ & $4.18(.62)$ & $4.55(.20)$ \\
\hline $\begin{array}{l}\text { Overall, the instructor was an effective } \\
\text { teacher }\end{array}$ & $2.08(0)$ & $4.00(.75)$ & $4.53(.2 \mathrm{I})$ \\
\hline I've learned a great deal in this course & $2.83(0)$ & $4.23(.46)$ & $4.40(.19)$ \\
\hline Overall, this was a worthwhile course & $\mathrm{I} .83(0)$ & $3.07(.72)$ & $3.47(.40)$ \\
\hline $\begin{array}{l}\text { Note. Mean values on a scale from I (strongly disagree) to } 5(\text { strongly agree). } \\
\text { Alignment determined by difference in syllabus score and COPUS category } \\
\text { outlined in Table 3. }\end{array}$ \\
\hline
\end{tabular}


Conversely, students' perceptions and self-reported learning were highest for courses that were considered fully aligned. These included one course with a content-focused syllabus and didactic instruction and seven courses with learning-focused syllabi and student-centered instruction. Regardless of structure, students overall liked instructors with fully aligned courses. For the aligned lecture-based course, one student commented:

The professor was helpful and responsive to different students needs. He is a very engaging teacher and you can tell he is passionate about this subject. I wish he would have spent more time on each slide, though! It was sometimes hard to take notes because it was at times fast paced. (SET)

Other students in the course held similar sentiments that this instructor was passionate and engaging in his lecture.

In one of the aligned learning-focused courses, students similarly commented on the enthusiasm of the instructor, stating "I enjoyed the course a lot. The material was interesting and an enthusiastic professor always makes it more fun to learn" (SET). However, there were additional comments about the learning students achieved in the class. For example, one student commented:

Great class that teaches you about the complexities of aging, why we age, and about the many factors and contributors associated with the aging process. Material is very interesting, and the class teaches you how to better read and understand published studies. (SET)

Thus, while aligned courses had higher ratings for participants in the program, student comments in the aligned learning-focused courses discussed both instructor likeability and learning.

\section{DISCUSSION}

In summary, the program helped instructors create more learning-focused courses and implement student-centered instructional strategies to differing degrees. Despite the supports for faculty while they were implementing their course re-design, there still existed barriers to implementation that included institutional structures and internal beliefs. Students' perceptions of course instruction and self-reported learning in the courses highlighted the importance of in-class activities. Finally, when the course design and instructional practice were aligned, students had more positive perceptions and reported higher learning gains.

\section{Implementation of Student-centered Instruction}

While faculty perceptions and observed practices cannot be linked, it is clear that variations existed in the ways faculty implemented student-centered instruction. Some faculty chose to integrate small changes into their lectures while others redesigned class time around structured group work. These differences could potentially be attributed to the barriers faculty perceived when implementing student-centered instructional practices. The findings in the present study align with previous work citing both internal (e.g., beliefs, agency, efficacy) and external (e.g., departmental norms, institutional cultures) barriers to instruction (Sturtevant \&Wheeler, 2019). The program that served as the context for this study focused on reducing internal barriers rather than external barriers. As described above, one of the goals of the program was to improve faculty confidence in implementing student-centered instruction. While confidence appeared to improve, the data suggest not all faculty beliefs aligned with the use of student-centered instruction. Knowing the importance of faculty beliefs on practice (Robert \& Carlsen, 2017), this may be one explanation for varied use of instructional practices that center students. Future work interviewing faculty about their instructional decisions as well as exploring the link between PD and faculty beliefs, self-efficacy, and practice using direct measures is warranted.

Alternatively, the external barriers faculty faced within their classroom spaces and departments may have contributed to the varied levels of student-centered instructional practices implemented. With the shift in CTL roles to focus on organizational development (Kelly, Cruz, \& Fire, 20I7), there are potential opportunities for CTL involvement in reducing external barriers for faculty. While previous work has explored the change mechanisms most impactful for STEM undergraduate instruction (Henderson, Beach, and Finkelstein, 20I4), further understanding institutional infrastructure and its relationship to institutional teaching culture and instructional practice is vital.

\section{Student Perceptions of Instructional Practices}

The findings presented above suggest that student perceptions of student-centered instructional practices varied widely, even for individual students. For example, despite appreciating group work, one student found it frustrating. A previous study of STEM large enrollment courses found that students' anxiety may impact the way that they interpret different types of active learning activities (Cooper et al., 2018), which may help explain the variation across student perceptions in the present study. A recent study also found that students in active learning classrooms perceive they learn less than when in traditional lectures, despite the opposite being true (Deslauriers et al., 2019). These differences in perceived learning and actual learning may explain the limited amount of discussion of learning within SET comments. Future work comparing student perceptions of learning-focused courses from SETs and other measures would be an important step in understanding the impact of student-centered instructional practices in STEM. Further understanding these perceptions and learning for sub-groups of students would also contribute to the literature on SETs and STEM in higher education.

Student perceptions data from SETs also illustrate how well students pick up on issues of misalignment in their courses. For example, students in the present study were able to identify when the syllabus and classroom instruction were misaligned. The use of a backward design approach for course redesign is common in CTLs (e.g., Palmer et al., 2016); however, there are few studies, to my knowledge, that seek to understand the translation of a course design into practice. A previous study of TAs' practice in a chemistry lab suggest that implementation of the same curriculum can vary widely (Velasco et al., 2016). The work of Velasco et al. (2016) in combination with the findings I presented here may suggest that instructor intention (i.e., syllabus) and action (i.e., instruction) are not synonymous. Mediating factors may include beliefs, barriers, and pedagogical content knowledge (Gess-Newsome, 20I5). More work exploring the relationship between syllabi and instruction is needed, particularly for redesigned courses.

\section{LIMITATIONS}

There are three main limitations to the present study that should be noted. First, the small sample size precludes general- 
izability of the results to other similar programs. Second, while I explored syllabi pre- and post-CDI, there was no control group for comparison of other measures. Thus, I cannot know if the results presented above are due to participation in the program. However, our previous work comparing faculty pre/post-FLC data (Favre, Bache, \& Wheeler, 202I) and and comparing FLC faculty to control faculty (Wheeler \& Bach, 2020) as well as faculty perceptions of the FLC presented in the present study suggest the program played an important role in faculty's course design and implementation. Third, similar to previous studies on PD program impact (e.g., Meizlish et al, 2017), I utilized SETs as a proxy for student perceptions of instruction and learning. Given the evaluation response rate (i.e., 67\%) for the courses presented in this study as well as previous research on bias in SETs (eg., Linse, 2016), course evaluations are not the most accurate measure for student perceptions and self-reported learning.

\section{IMPLICATIONS}

The present study demonstrates how a CTL program that couples a week-long intensive course design institute with a faculty learning community can support faculty who teach large-enrollment STEM courses. The findings of the present study contribute to the PD literature and suggest the multifaceted PD approach improved faculty's understanding of and confidence in using learning-focused course design and student-centered instructional practices. By situating these findings in the educational development literature (e.g., Stes et al., 20 I0), STEM PD literature (e.g.,Ebert-May et al., $20 \mathrm{II}$ ), and PD literature on best practices (e.g., Desimone, 2009; Luft \& Hewson, 20I4), I have identified four characteristics that other educational developers may consider when developing PD programs to enable STEM faculty to make meaningful and lasting changes to practice:

- Coherency - PD programs should include components with common goals rather than discrete components with no coherency (Desimone, 2009; Rathbun et al.,2016).Additionally, PD programs focused both on backward and integrated course design can promote course alignment (Palmer et al., 2016).

- $\quad$ Feedback \& reflection - Faculty need opportunities to receive feedback on their teaching and/or course materials (Czajka \& McConnell, 2016). Further, opportunities to reflect on ideas learned from peers as well as course feedback may help promote change (Huball et al., 2005).

- $\quad$ Structure - Providing structure within the PD and/ or scaffolded materials can help reduce barriers and support change (Hutchins \& Friedrichson, 2012; Pelch \& McConnell, 2016).

- Collective participation - Faculty should have opportunities to engage and collaborate with inter- and intra-disciplinary faculty learning communities focused on teaching (e.g., Desimone, 2009). Further, participation of faculty teams working on a group of courses can be helpful in reducing departmental barriers (EbertMay et al., 20I I;Tomkin, et al., 2019).

In this study, I have also illustrated how multiple data sources can be utilized to demonstrate the impact of a PD program on faculty instructional practices and students' self-reported learning. However, this multi-pronged approach to assessing program impact can be time consuming, and without proper resources is not a sustainable approach for CTL assessment. Making decisions about which programs to assess, what to assess, and when to assess can help enable this type of work. Coupling scholarship with program improvement can also help CTLs move beyond collecting participant satisfaction data to more robust assessment practices (Hurney et al., 20I6). While this work is challenging, the more we can do to understand and improve STEM instruction the more we can support all students in succeeding in these courses.

\section{ACKNOWLEDGEMENTS}

I would like to acknowledge Michael Palmer, Director in the Center for Teaching Excellence at the University of Virginia, who led the program. I would also like to acknowledge Archie Holmes, former Vice Provost for Academic Affairs at the University of Virginia, for funding the program.

\section{NOTES}

I. For more details on the efficacy of CDI, see (Palmer et al., 20I6). 2. Normalized gain was calculated using the equation (post-pre)/(46pre) $\times 100$

3. Participants in Year I were observed using a different protocol. Data from Year I suggest a similar pattern in instructional practice to Years 2 \& 3.

4. I understand the use of SETs as a data source can be problematic; however, I couple the Likert and open-ended SET questions along with other data sources to provide a more comprehensive understanding of impact.

5. Given the potential for bias in course evaluations (Linse, 2016) I analyzed the means for each course based on instructor gender. No significant differences existed between instructor genders on any of the individual questions.

\section{REFERENCES}

Birt, J.A., Khajeloo, M., Rega-Brodsky, C. C., Siegel, M.A., Hancock, T. S., Cummings, K., \& Nguyen, P. D. (20/9). Fostering agency to overcome barriers in college science teaching: Going against the grain to enact reform-based ideas. Science Education, I03(4), 770-798. https://doi.org//0.1002/sce.21519

Cooper, K. M., Downing, V. R., \& Brownell, S. E. (20I8). The influence of active learning practices on student anxiety in large-enrollment college science classrooms. International Journal of STEM Education, 5(I), 23. https://doi.org/10.1 186/ s40594-018-0123-6

Cox, M. D. (2004). Introduction to faculty learning communities. New directions for teaching and learning, 2004(97), 5-23.

Creswell, J.W., \& Clark, V. L. (20I I). Choosing a mixed methods design. In Designing and Conducting Mixed Method Research (pp. 53-107).

Czajka, C. D., \& McConnell, D. (2016). Situated instructional coaching: a case study of faculty professional development. International Journal of STEM Education, 3(I), I-I4. https://doi. org/ I 0. I I 86/s40594-0 I6-0044- I

Deslauriers, L., McCarty, L. S., Miller, K., Callaghan, K., \& Kestin, G. (2019). Measuring actual learning versus feeling of learning in response to being actively engaged in the classroom. Proceedings of the National Academy of Sciences of the United States of America, I-7. https://doi.org/I0.1073/pnas. I82 I936I I6 
Ebert-May, D., Derting, T. L., Hodder, J., Momsen, J. L., Long,T. M., \& Jardeleza, S. E. (20I I). What We Say Is Not What We Do: Effective Evaluation of Faculty Professional Development Programs. BioScience, 6/(7), 550-558. https://doi.org/I0.I525/ bio. 2011.61 .7 .9

Eiselein, G. (2019). Designing, implementing, and sustaining faculty development: A model for large and diverse FYE programs. The Journal of Faculty Development, 33(2), 43-48.

Eren-Sisman, E. N., Cigdemoglu, C., \& Geban, Ö. (2018). The Effect of Peer-Led Team Learning on Undergraduate Engineering Students' Conceptual Understanding, State Anxiety, and Social Anxiety. Chemistry Education Research and Practice. https://doi.org//0.1039/C7RP0020IG

Favre, D., Bach, D., \&Wheeler, L.B. (202I). Measuring institutional transformation:A multi-faceted assessment of a new faculty development program. Journal of Research in Innovation Teaching \& Learning. DOI: I0.1 I08/JRIT-04-2020-0023

Fink, L. D. (2013). Creating significant learning experiences: An integrated approach to designing college courses. John Wiley \& Sons.

Freeman, S., Eddy, S. L., McDonough, M., Smith, M. K., Okoroafor, N., Jordt, H., \& Wenderoth, M. P. (20I4). Active learning increases student performance in science, engineering, and mathematics. PNAS, I/I/(23), 84I0-84/5. https://doi. org/ I0.1073/pnas. I 3 I 9030 I I I

Gehrke, S., \& Kezar,A. (2017). The Roles of STEM Faculty Communities of Practice in Institutional and Departmental Reform in Higher Education. American Educational Research Journal, XX(X), I-3 I. https://doi.org/ / 0.3 I02/000283 I 217706736

Gibbs, G., \& Coffey, M. (2004). The Impact Of Training Of University Teachers on their Teaching Skills, their Approach to Teaching and the Approach to Learning of their Students. Active Learning in Higher Education, 5(I), 87-100. https://doi. org/l0. I I 77//469787404040463

Haak, D. C., HilleRisLambers, J., Pitre, E., \& Freeman, S. (20I I). Increased structure and active learning reduce the achievement gap in introductory biology. Science, 332(June), I2131217.

Hayward, C. N., \& Laursen, S. L. (2018). Supporting instructional change in mathematics: using social network analysis to understand online support processes following professional development workshops. International Journal of STEM Education, 5(I). https://doi.org/I0.I I86/s40594-0 I8-0 I 20-9

Hubball, H., Collins, J., \& Pratt, D. (2005). Enhancing Reflective Teaching Practices: Implications for Faculty Development Programs. The Canadian Journal of Higher Education, 35(3), 56-8I.

Hurney, C.A., Brantmeier, E. J., Good, M. R., Harrison, D., \& Meixner, C. (2016). The faculty learning outcome assessment framework. The Journal of Faculty Development, 30(2), 69-77.

Hutchins, K. L., \& Friedrichsen, P. J. (20I2). Science Faculty Belief Systems in a Professional Development Program: Inquiry in College Laboratories. Journal of Science Teacher Education, 23(8), 867-887. https://doi.org/ I 0.1007/s I0972-0 I 2-9294-z

Jones, F. (2018). Comparing student, instructor, classroom and institutional data to evaluate a seven-year department-wide science education initiative. Assessment and Evaluation in Higher Education, 43(2), 323-338. https://doi.org/10.1080/0 2602938.2017.1343799
Kelley, B., Cruz, L., \& Fire, N. (2017). Moving toward the center: The integration of educational development in an era of historic change in higher education. To Improve the Academy, 36(I), I-8.

Kuh, G. D., Cruce, T.M., Kinzie, J. \& Gonyea, R.M. (2008). Unmasking the Effects of Student Engagement on First-Year College Grades and Persistence. The Journal of Higher Education, 79(5), 540-563. https://doi.org/10.1353/jhe.0.0019

Lauridsen, K. M., \& Lauridsen, O. (2018). Teacher capabilities in a multicultural educational environment: an analysis of the impact of a professional development project. International Journal for Academic Development, 23(2), 98-109. https://doi. org/10.1080/1360144X.2017.1357557

Linse, A. R. (2017). Interpreting and using student ratings data: Guidance for faculty serving as administrators and on evaluation committees. Studies in Educational Evaluation, 54, 94106. https://doi.org/ 10.1016/j.stueduc.2016.12.004

Meizlish, D. S.,Wright, M. C., Howard,J., \& Kaplan, M.L. (20I8). Measuring the impact of a new faculty program using institutional data. International Journal for Academic Development, 23(2), 72-85. https://doi.org/ I0.1080/1 360 I 44X.20 I7.1364644

Miles, M. B., \& Huberman,A. M. (1994). Qualitative data analysis:An expanded sourcebook. Sage.

Ödalen, J., Brommesson, D., Erlingsson, G. Ó., Schaffer, J. K., \& Fogelgren, M. (20I8). Teaching university teachers to become better teachers: the effects of pedagogical training courses at six Swedish universities. Higher Education Research \& Development, O(0), I-I5. https://doi.org/I0.1080/07294360.20 I 8.1512955

Palmer, M. S., Bach, D. J., \& Streifer, A. C. (20/4). Measuring the promise: A learning-focused syllabus rubric. To Improve the Academy, 33(I), 14-36

Palmer, M. S., Streifer, A. C., \& Williams-Duncan, S. (20 I6). Systematic Assessment of a High-Impact Course Design Institute. To Improve the Academy, 35(2), 339-36I.

President's Council of Advisors on Science and Technology (PCAST). (20I2). Engage to excel: producing one million additional college graduates with degrees in science, technology, engineering, and mathematics. Washington, D. C.: Office of Science and Technology Policy.

Rathbun, G.A., Leatherman, J., \& Jensen, R. (2016). Evaluating the impact of an academic teacher development program: practical realities of an evidence-based study. Assessment \& Evaluation in Higher Education, I-I6. https://doi.org/I0.1080/026 02938.2016 .1161004

Robert, J., \& Carlsen, W. S. (2017). Teaching and research at a large university: Case studies of science professors. Journal of Research in Science Teaching, 54(7), 937-960. doi. org/I0.1002/tea.21392.

Schneider, M., \& Preckel, F. (2017). Variables associated with achievement in higher education: A systematic review of meta-analyses. Psychological Bulletin, I43(6), 565-600. https:// doi.org// 0.1037/bul0000098

Stains, M., Harshman, J., Barker, M. K., Chasteen, S. V., Cole, R., DeChenne-Peters, S. E., ... Young, A. M. (2018). Anatomy of STEM teaching in North American universities-Supplemental materials. Science, 359(6383), |468-|470. https://doi. org/ I0.1 126/science.aap8892

Stes, A., Min-Leliveld, M., Gijbels, D., \& Van Petegem, P. (20I0). The impact of instructional development in higher education:The 
state-of-the-art of the research. Educational Research Review, 5(I), 25-49. https://doi.org//0.1016/j.edurev.2009.07.00 I

Sturtevant, H. \& Wheeler, L. (2019). The STEM Faculty Instructional Barriers and Identity Survey (FIBIS): Development and exploratory results. International Journal of STEM Education, 6(35), I-22. DOI: I0.I I86/s40594-019-0I85-0

Sunal, D.W., Hodges, J., Sunal, C. S.,Whitaker, K.W., Freeman, L. M., Edwards, L., ... Odell, M. (200I). Teaching science in higher education : Faculty professional development and barriers to change. School Science and Mathematics, I0I(5), 246-257. https://doi.org/I0.I I I I/j. I949-8594.200 I.tb I8027.x

Tomkin, J. H., Beilstein, S. O., Morphew, J. W., \& Herman, G. L. (2019). Evidence that communities of practice are associat- ed with active learning in large STEM lectures. International Journal of STEM Education, 6(I), I-I5.

Velasco, J. B., Knedeisen, A., Xue, D., Vickrey, T. L., Abebe, M., \& Stains, M. (2016). Characterizing Instructional Practices in the Laboratory: The Laboratory Observation Protocol for Undergraduate STEM. Journal of Chemical Education, 93, ||9|-|203. https://doi.org/|0.1021/acs.jchemed.6b00062

Wheeler, L. \& Bach, D. (202I). Understanding the Impact of Educational Development Interventions on Classroom Instruction and Student Success. International Journal of Academic Development, 26(I), 24-40. DOI:I0.1080/I360I4 4X.2020.1777555 